\title{
Pharmacological Interventions on The Dopamine Motivation System Effectively Disturbed Cue- Induced Memory Reconsolidation Cocaine-Seeking Behavior for Rats
}

\section{Yang Li}

Department of Neurosurgery, Tangdu Hospital, the Fourth Military Medical University Nan Li

Department of Neurosurgery, Tangdu Hospital, the Fourth Military Medical University Liang Qu

Department of Neurosurgery, Tangdu Hospital, the Fourth Military Medical University

\section{Xin Wang}

Department of Neurosurgery, Tangdu Hospital, the Fourth Military Medical University

\section{Ping Wang}

Department of Neurosurgery, Tangdu Hospital, the Fourth Military Medical University Jian Fu

Department of Neurosurgery, Tangdu Hospital, the Fourth Military Medical University

\section{Yu-kun Chen}

Department of Neurosurgery, Tangdu Hospital, the Fourth Military Medical University

\section{Jian-cai Wang}

Department of Neurosurgery, Tangdu Hospital, the Fourth Military Medical University

\section{Shun-nan Ge}

Department of Neurosurgery, Tangdu Hospital, the Fourth Military Medical University

\section{Xue-lian Wang ( $\nabla$ tdwxlian@126.com )}

Department of Neurosurgery, Tangdu Hospital, the Fourth Military Medical University

\section{Research Article}

Keywords: Dopamine motivation system, Cue-induced, Self-administration, Memory reconsolidation, Behavior, Cocaine

Posted Date: April 30th, 2021

DOl: https://doi.org/10.21203/rs.3.rs-426726/v1 
License: (c) (i) This work is licensed under a Creative Commons Attribution 4.0 International License. Read Full License 


\section{Abstract}

Drug addiction is a disorder related to dysfunction in the neural reward memory circuits, and it is characterized by compulsive drug use despite terrible negative consequences. Memory reconsolidation, during which aroused memory is easy to strengthening, weakening or updating, plays an extremely important role in drug addiction. Effectively interfering with the drug memory reconsolidation process would be key in treating drug addiction, but this intervention currently remains impossible. The dopamine motivation system has been widely recognized as an important system for reward, but whether the dopamine motivation system participates in drug memory reconsolidation is unclear. We aimed to explore the role of the dopamine motivation system during the cue-induced cocaine memory reconsolidation process by examining the effect of different pharmacological interventions on the dopamine motivation system during cue-induced cocaine self-administration-related memory reconsolidation drug-seeking behavior. Using a combined behavioral and biological method, our results showed that high concentrations of SCH 23390 and raclopride, or VTA lesions, could effectively disturb subsequent cue-induced cocaine self-administration-related memory reconsolidation drug-seeking behavior in rats. However, low concentrations of SCH 23390 and raclopride could not block this behavior. In summary, only a high dose of dopamine $\mathrm{D}_{1}$ and $\mathrm{D}_{2}$ receptor antagonists, or VTA lesions, could effectively disturb subsequent cue-induced cocaine self-administration-related memory reconsolidation drug-seeking behavior. These findings indicated that pharmacological interventions in the dopamine motivation system could effectively disturb subsequent cue-induced drug memory reconsolidation. Thus, pharmacological interventions on the dopamine motivation system might have therapeutic potential for drug addiction.

\section{Introduction}

Drug addiction is a disorder related to dysfunction in the neural reward memory loop that is characterized by compulsive drug use despite terrible negative consequences (Hyman, Malenka, \& Nestler, 2006; Y. Li et al., 2016). Through associative learning, drug-paired environmental stimuli could have very powerful influence on drug-seeking behavior; therefore, drug memory reconsolidation critically underlies persistent drug-seeking behavior. Drug-related memory could be reactivated after re-exposure to drug-paired environmental stimuli (Namely, cues) or the drug itself (Everitt, Giuliano, \& Belin, 2018; Gauthier et al., 2017; Torregrossa \& Taylor, 2016), and a relapse in drug-seeking behavior could occur(Childress et al., 1999). Further studies will need to be powerful enough to diminish drug-seeking behavior under drugpaired environmental stimuli. Therefore, extinguishing the impact of drug-paired environmental stimuli is an extremely important goal for the valid treatment of drug addiction(Gauthier et al., 2017).

Environmental stimuli can improve learning and memory and induce neuroplasticity in the brain(Sale, Berardi, \& Maffei, 2014; van Praag, Kempermann, \& Gage, 2000). In many previous studies, environmental stimuli included a lot of condition in which experimental animals had access to cognitive stimulation, social and physical (Thiel et al., 2012; Thiel, Sanabria, Pentkowski, \& Neisewander, 2009; van Praag et al., 2000). In rodent drug addiction experiments, there are two main classic animal models: the conditioned 
place preference (CPP) model and the self-administration (SA) model. Most studies examining the effects of environmental stimuli on experimental animals have used relatively long-term enriched housing conditions over several days(Chauvet, Lardeux, Goldberg, Jaber, \& Solinas, 2009).

Many studies demonstrated that pharmacological manipulations of several neurotransmitters and relevant receptors, mostly including glutamatergic, dopaminergic and $\beta$-adrenergic receptors, could have an important effect on memory reconsolidation(Diergaarde, Schoffelmeer, \& De Vries, 2008; Y. Li et al., 2016) and could also lead to an absence of the subsequent CPP memory(Brown, Lee, \& Sorg, 2008; Otis \& Mueller, 2011; Spina, Fenu, Longoni, Rivas, \& Di Chiara, 2006). Dopamine (DA) is a catecholamine neurotransmitter in the mesocorticolimbic system(Chen et al., 2017). DA plays important roles in many aspects of cognition, including reward, punishment, attention, learning and memory (Smythies, 2005). Dysfunction in DA and DA neurons could lead to neurological and psychiatric diseases, such as drug addiction, Parkinson's disease, schizophrenia, hyperprolactinemia and Tourette's syndrome (Belliotti et al., 1999; Zhang et al., 2007). After chronic exposure to several kinds of addictive substances, many molecular and cellular adaptive changes that occur in the DA mesocorticolimbic system may contribute to drug addiction. Neuroadaptations in the dopamine motivation system could mediate enhanced motivation towards related reinforced predictors. Cocaine inhibited the clearance of dopamine from the synaptic cleft by blocking plasma membrane monoamine transporters.

The role of dopamine (DA) in motivated behaviors and cognitive processes has been well established. The DA motivation system mainly includes DA neurons in the ventral tegmental area (VTA) and the substantia nigra (SN). On the one hand, limbic structures, including the hippocampus and nucleus accumbens, which have traditionally been associated with motivation and reinforcement learning, receive dopaminergic innervation from the VTA, which is known to be a key dopaminergic center in the brain(Gasbarri, Sulli, \& Packard, 1997; Wahlstrom, White, \& Luciana, 2010). On the other hand, DA neurons in the SN mainly project to the dorsal striatum, which has traditionally been associated with action selection, goal-directed behavior and the emergence of habits(Howard, Li, Geddes, \& Jin, 2017; Wise, 2009; Yager, Garcia, Wunsch, \& Ferguson, 2015). More importantly, the dopamine motivation system, as a driver of reinforcement, acts as the neurobiological basis of drug addiction(Drugs \& Crime, 2010; Koob \& Volkow, 2010; Volkow, Wise, \& Baler, 2017). Several studies have demonstrated a critical role for dopamine in the reward circuit. The pharmacological agents that were previously used to target the dopamine system in animal models mainly acted on dopamine $D_{1}$ and $D_{2}$ receptors. Several recent studies have highlighted a role for other subfamilies of receptors(Fraser, Haight, Gardner, \& Flagel, 2016).

In this study, to test the hypothesis that interventions targeting on the dopamine motivation system could affect drug memory reconsolidation, we employed a cue-induced cocaine self-administration paradigm to explore the effect of pharmacological interventions on rebalancing the dopamine motivation system and on cue-induced cocaine SA-related memory reconsolidation drug-seeking behavior. These results might help us to elucidate the neuropharmacological mechanism underlying the function of the dopamine motivation system during drug memory reconsolidation. 


\section{Materials And Methods}

\section{Animals}

All experimental procedures in our study were consistent with the guidelines of the Committee for Animal Care and Use (No. TDLL2018-03-180, Tangdu Hospital, the Fourth Military Medical University, Xi'an, Shaanxi, China). And the experimental protocols were approved by the Committee for Animal Care and Use of Tangdu Hospital, the Fourth Military Medical University. Sprague-Dawley rats (Male; $300 \sim 350 \mathrm{~g}$ ) were individually housed in our animal center under controlled temperature $\left(21 \pm 2^{\circ} \mathrm{C}\right)$ and humidity (40\% 60\%) on a 12-hour light-dark cycle (lights on at 7:00 a.m.), and they were provided with food and water ad libitum.

\section{Drug preparation}

Cocaine hydrochloride (Qinghai Pharmaceutical Co. Ltd., Xining, Qinghai, China), which was dissolved in saline to a final concentration of $8 \mathrm{mg} / \mathrm{mL}$, was stored at room temperature away from light.(Y. Li et al., 2016) 6-hydroxydopamine (6-OHDA, $10 \mu \mathrm{g} / \mu \mathrm{L}, \mathrm{H} 4381-100 \mathrm{MG}$, Sigma-Aldrich. Co. USA) was dissolved in $0.2 \mathrm{mg} / \mathrm{mL}$ ascorbic acid and $0.9 \% \mathrm{w} / \mathrm{v}$ saline solution and stored at $-20^{\circ} \mathrm{C}$ away from light. $\mathrm{SCH} 23390$ (dopamine $D_{1}$ receptor antagonist, $2 \mu \mathrm{g} / \mu \mathrm{L}$, D054-5 MG, Sigma-Aldrich. Co. USA) was dissolved in $0.9 \%$ $\mathrm{w} / \mathrm{v}$ saline solution and stored at $-20^{\circ} \mathrm{C}$ away from light. Raclopride (dopamine $\mathrm{D}_{2}$ receptor antagonist, 10 $\mu \mathrm{g} / \mu \mathrm{L}, \mathrm{R} 121-25 \mathrm{MG}$, Sigma-Aldrich. Co. USA) was dissolved in $0.9 \% \mathrm{w} / \mathrm{v}$ saline solution and stored at $-20^{\circ} \mathrm{C}$ away from light.

\section{Surgical procedure}

\section{Jugular vein catheterization surgery}

Rats were anesthetized with sodium pentobarbital (50 mg/kg body weight, i.p.) and fixed in the prone position. A skin opening approximately $0.8 \mathrm{~cm}$ in length was cut longitudinally in the right neck to fully expose the right jugular vein. A sterile special silicone catheter was inserted into the right jugular vein. Following surgery, the jugular vein catheter was rinsed daily with saline containing heparin $(10 \mathrm{U} / \mathrm{mL})$ and penicillin $(200,000 \mathrm{IU} / \mathrm{rat})$ to prevent catheter blockage and infection, respectively.

\section{VTA lesion surgery}

After anesthetization, the rats in the VTA-lesioned group were fixed in a stereotaxic apparatus (68025, RWD Life Science Co., Ltd, Shenzhen, Guangdong, China) in the prone position(Y. Li et al., 2016). 6-OHDA $(10 \mu \mathrm{g} / \mu \mathrm{L}, 0.8 \mu \mathrm{L})$ was intracranially infused into the VTA (according to the rat stereotaxic atlas (Paxinos and Watson, 2005): $-5.20 \mathrm{~mm}$ anterior to bregma, $0.80 \mathrm{~mm}$ lateral to the midline (left side), and $8.80 \mathrm{~mm}$ ventral to the brain surface) using $1 \mu \mathrm{L}$ Hamilton syringes (Plastics One) at a rate of $0.1 \mu \mathrm{L} / \mathrm{min}$ for every rat. The injection needle was held in place for an additional 15 min so that 6-OHDA could completely diffuse from the needle tip.

\section{Drug self-administration apparatus}


The self-administration (SA) apparatus $(40 \mathrm{~cm} \times 40 \mathrm{~cm} \times 50 \mathrm{~cm}$; AniLab Co., Ltd., Ningbo, Zhejiang, China) received an input signal once the rat made a valid nose poke into the port, and then, it could produce as many output signals as we required (for example, for the pump, signal lights, nose poke light, or sound). According to the experimental requirements, we first needed to edit an appropriate experimental method (fixed ratio, $F R=1$ ). Specifically, when a rat finished a valid nose poke, the system would pump one bolus of drug ( $T=1.25 \mathrm{~s}, \mathrm{v}=1.60 \mathrm{~mL} / \mathrm{min})$, accompanied by several changes in environmental cues such as the signal lights (green light is off, and red light is on for $20 \mathrm{~s}$ ), valid nose poke light $(T=20 \mathrm{~s}$ ), and sound (buzzer, $T=1.25 \mathrm{~s}$ ). Every time a valid nose poke was completed, the system would immediately enter into a 20-s refractory period. Then, the system would enter into the next cycle (green light would remain on until the next valid nose poke).

\section{Drug self-administration training procedure and cue-induced drug addictive memory reconsolidation procedure}

After $3 \mathrm{~d}$ of recovery following jugular vein catheterization surgery, all rats underwent a drug selfadministration training procedure on a 14-day training schedule (Fig. 1). Training lasted $2 \mathrm{~h}$ per day, and the number of nose pokes (valid nose poke and invalid nose poke) and the number of pumps (with drug) were recorded.

In our study, when the number of valid nose pokes increased significantly and reached a relatively stable level at the end of the training period (varying less than 3 times or $15 \%$ for three consecutive days), the drug SA model for rats was considered basically successful.

After the successful establishment of the SA model, the rats began the memory reconsolidation procedure. Experimental rats were again placed into the SA apparatus for $2 \mathrm{~h}$. When rats finished a "valid" nose poke, the system would only provide the related environmental cues without pumping cocaine.

\section{Tissue preparation}

After deep anesthetization, rats were transcardially perfused with $200 \mathrm{~mL}$ of ice-cold $0.1 \mathrm{M}$ sodium phosphate-buffered saline (PBS; $\mathrm{pH} 7.4$ ), followed by $400 \mathrm{~mL}$ of $4 \%(\mathrm{w} / \mathrm{v})$ paraformaldehyde in $0.1 \mathrm{M} \mathrm{PB}$. The brains were removed and postfixed at $4^{\circ} \mathrm{C}$ overnight in $4 \%(\mathrm{w} / \mathrm{v})$ paraformaldehyde in $0.1 \mathrm{M} \mathrm{PB}$. After cryoprotection with $30 \%(\mathrm{w} / \mathrm{v})$ sucrose in $0.1 \mathrm{M} \mathrm{PB}$, the brain was sliced into $30 \mu \mathrm{m}$-thick transverse sections using a cryostat $\left(-20^{\circ} \mathrm{C}\right)$. The brain sections including the VTA were stored in freeze protection solution (Ethylene glycol: Glycerol: PBS = 3:3:4).

\section{Immunohistochemical staining}

The sections were first incubated at room temperature in $0.3 \%$ Triton X-100 for $20 \mathrm{~min}, 3 \%$ hydrogen peroxide for $15 \mathrm{~min}$ and normal goat serum for $30 \mathrm{~min}$. Then, the sections were incubated sequentially at room temperature as follows: Firstly, anti-tyrosine hydroxylase (TH) mouse $\lg \mathrm{G}(1 \mu \mathrm{g} / \mathrm{mL}$, ab129991, Abcam, Cambridge, UK) for $24 \mathrm{~h}$ at $4^{\circ} \mathrm{C}$. Secondly, a biotinylated goat antibody against mouse Ig G (SP9002, ZSGB-BIO, Beijing, China) at room temperature for 30 min(Y. Li et al., 2016). Thirdly, avidin- 
conjugated horseradish peroxidase at room temperature for $30 \mathrm{~min}$, and then peroxidase activity was visualized after an approximately 3-min reaction with DAB Kit (ZLI-9018, ZSGB-BIO, Beijing, China). Finally, the sections were mounted on gelatin-coated slides, dried, dehydrated in increasing concentrations of ethanol, cleared with xylene, and cover-slipped with neutral balsam(Y. Li et al., 2016). Next, digital images were captured with an ordinary optical microscope (Eclipse E100, Nikon, Nikon Instruments (Shanghai) Co., Ltd., China), modified (15 20\% contrast enhancement) with Photoshop CS6 (Adobe Systems, San Jose, CA, USA), and saved as TIFF files(Li et al., 2020).

\section{Statistical analysis}

All results in this experiment were expressed as the means \pm SEM. The data were statistically assessed via Student's two-tailed t-test and one-way ANOVA using SPSS 18.0 (SPSS Inc., USA). P values of less than 0.05 were accepted as statistically significant. All group data in our study are reported in the table or figure legends.

\section{Ethics}

All experimental procedures in our study were consistent with the guidelines of the Committee for Animal Care and Use (No. TDLL2018-03-180, Tangdu Hospital, the Fourth Military Medical University, Xi'an, Shaanxi, China). And the study procedures were carried out in accordance with the Declaration of Helsinki.

\section{Results}

\section{Establishment of cocaine self-administration (SA) model for rats}

In this experiment, all rats $(\mathrm{n}=70)$ were divided into two groups: the Saline group $(\mathrm{n}=8)$ and the Cocaineaddicted group $(n=62)$. During cocaine SA training, many rats can be removed due to a number of complications, for example, failed jugular vein catheterization surgery (e.g., leaking, blockage, serious infection, etc.). Overall, 7 of 70 rats in the Saline group (1/8) and the Cocaine-addicted group (6/62) were removed (see Table 1). 
Table 1

Design and grouping in our experiment

\begin{tabular}{|c|c|c|c|c|c|}
\hline & \multirow{2}{*}{$\begin{array}{l}\text { Saline } \\
\text { group }\end{array}$} & \multicolumn{4}{|c|}{ Cocaine-addictive group } \\
\hline & & $\begin{array}{l}\text { Control } \\
\text { group }\end{array}$ & $\begin{array}{l}\text { VTA- lesioned } \\
\text { group }\end{array}$ & $\begin{array}{l}\text { SCH } 23390 \\
\text { group }\end{array}$ & $\begin{array}{l}\text { Raclopride } \\
\text { group }\end{array}$ \\
\hline Total & $\mathrm{n}=8$ & $n=62$ & & & \\
\hline SA training & $-1^{a}$ & $-6^{a}$ & & & \\
\hline $\begin{array}{l}\text { Successful } \\
\text { SA model }\end{array}$ & $\mathrm{n}=7$ & $\mathrm{n}=56$ & & & \\
\hline Grouping & $\mathrm{n}=7$ & $\mathrm{n}=6$ & $\mathrm{n}=8$ & $\mathrm{n}=21$ & $\mathrm{n}=21$ \\
\hline \multirow[t]{3}{*}{$\begin{array}{l}\text { Sub- } \\
\text { grouping }\end{array}$} & $\mathrm{n}=7$ & $\mathrm{n}=6$ & $\mathrm{n}=8$ & $\begin{array}{l}0.02 \mathrm{mg} / \mathrm{kg}^{\beta}(\mathrm{n}= \\
7)\end{array}$ & $\begin{array}{l}0.02 \mathrm{mg} / \mathrm{kg}^{\beta}(\mathrm{n}= \\
7)\end{array}$ \\
\hline & & & & 7) $0.20 \mathrm{mg} / \mathrm{kg}^{\beta}(\mathrm{n}=$ & $\begin{array}{l}0.10 \mathrm{mg} / \mathrm{kg}^{\beta}(\mathrm{n}= \\
\text { 7) }\end{array}$ \\
\hline & & & & 7) $0.50 \mathrm{mg} / \mathrm{kg}^{\beta}(\mathrm{n}=$ & $\begin{array}{l}0.20 \mathrm{mg} / \mathrm{kg}^{\beta}(\mathrm{n}= \\
\text { 7) }\end{array}$ \\
\hline
\end{tabular}

$(0.02,020,0.50,0.10) \mathrm{mg} / \mathrm{kg}^{\beta}$ presented a certain corresponding concentration of SCH $23390 /$ raclopride.

SA: Self-administration.

Figure $2 \mathrm{~A}$ and $2 \mathrm{D}$ showed the cocaine self-administration training procedure. Then, we performed statistical analysis on the rats' behavior according to the number of valid nose pokes in the first three days and the last three days in the Saline group $(n=7)$ and the Cocaine-addicted group $(n=56)$.

Compared to the first three days, we found that the number of valid nose pokes in the last three days in the Cocaine-addicted group increased significantly $\left(\mathrm{t}_{\text {Cocaine-addicted group }}=30.76, P<0.01\right.$; Fig. $2 \mathrm{~F}$ ) during the cocaine SA training period and remained relatively stable during the last three days of the training period $\left(\mathrm{F}_{\text {Cocaine-addicted group }}=0.1244, P=0.8831\right.$; Fig. $\left.2 \mathrm{E}\right)$. However, there was a slight decrease in the number of nose pokes in the Saline group $\left(\mathrm{t}_{\text {Saline group }}=2.977, P<0.01\right.$; Fig. $2 \mathrm{C}$ ), and the number of valid nose pokes reached a relatively stable level during the last three days of the training period $\left(F_{\text {Saline }}\right.$ group $=1.028, P=0.3777$; Fig. 2B).

In addition, the number of valid nose pokes in the last three days between the Cocaine-addicted group and the Saline group was significantly different ( $t_{\text {Cocaine-addicted group, Saline group }}=23.17, P<0.01$; Fig. $3 \mathrm{~A}$ ). Figure 3B showed several original recordings of the experimental rat's behavioral events. Figure $3 \mathrm{C}$ and 
3D Showed the change for cues before and after valid nose poke. The above results indicated that the Cocaine-addicted group had effectively established a cocaine self-administration model.

\section{Behavioral changes in the self-administration (SA) model for rats after different pharmacological manipulations in the dopamine pathway during cue-induced cocaine memory reconsolidation}

During the following 14-day withdrawal period, 56 rats in the Cocaine-addicted group remained randomly divided into several subgroups as follows: the Control group $(n=6)$, VTA-lesioned group $(n=8), S C H$ 23390 group $(\mathrm{n}=21,0.02 \mathrm{mg} / \mathrm{kg}(\mathrm{n}=7) ; 0.20 \mathrm{mg} / \mathrm{kg}(\mathrm{n}=7) ;$ or $0.50 \mathrm{mg} / \mathrm{kg}(\mathrm{n}=7))$, and Raclopride group $(\mathrm{n}=21,0.02 \mathrm{mg} / \mathrm{kg}(\mathrm{n}=7) ; 0.10 \mathrm{mg} / \mathrm{kg}(\mathrm{n}=7) ;$ or $0.20 \mathrm{mg} / \mathrm{kg}(\mathrm{n}=7))($ Table 1$)$.

After different pharmacological manipulations (intravenous injection, iv) in the dopamine pathway, the rats were placed in the SA apparatus for $2 \mathrm{~h}$. After our study, many coronal brain sections $(30 \mu \mathrm{m})$ in the target region in the VTA-lesioned group were processed using TH-immunohistochemical staining to confirm the location and range of VTA lesions (Fig. 4). Compare to the unlesioned side, the number of VTA dopamine neurons in the lesioned side reduced significantly $\left(n_{\text {lesioned }}=21.67 \pm 3.077, n_{\text {unlesioned }}=\right.$ $107.67 \pm 9.688, t=20.72, P<0.001$. not seen in Tables or Figures).

\section{Step 1: We analyzed the rats' behavior during drug self-administration training procedure in every group.}

Firstly, we found the number of valid nose poke in every Cocaine-addicted group increased significantly during cocaine $S A$ training period and it reached a relatively stable level during the last three days $\left(F_{\text {Control }}\right.$ group $=0.3360, P=0.7199 ; \mathrm{F}_{\mathrm{VTA} \text {-lesioned group }}=0.4505, P=0.6433 ; \mathrm{F}_{0.02} \mathrm{mg} / \mathrm{kg} \mathrm{sCH} 23390$ group $=0.5892, P=$ $0.5651 ; \mathrm{F}_{0.20 \mathrm{mg} / \mathrm{kg} \mathrm{SCH} 23390 \text { group }}=0.03359, P=0.9670 ; \mathrm{F}_{0.50 \mathrm{mg} / \mathrm{kg} \mathrm{sCH} 23390 \text { group }}=0.01210, P=0.9880 ; \mathrm{F}_{0.02}$ $\mathrm{mg} / \mathrm{kg}$ Raclopride group $=0.2750, P=0.7627 ; \mathrm{F}_{0.10 \mathrm{mg} / \mathrm{kg} \text { Raclopride group }}=0.03628, P=0.9644 ; \mathrm{F}_{0.20} \mathrm{mg} / \mathrm{kg}$ Raclopride group $=0.02997, P=0.9705 ;$ Fig. 5 and Fig. 6).

Secondly, we analyzed the rats' behavior in the same group. Compared to the number of valid nose pokes for the first three days, the number for the last three days showed a significant increase in every Cocaineaddicted group ( $\mathrm{t}_{\text {Control group }}=18.46, P<0.01 ; \mathrm{t}_{\mathrm{VTA} \text {-lesioned group }}=12.79, P<0.01 ; \mathrm{t}_{0.02} \mathrm{mg} / \mathrm{kg} \mathrm{SCH} 23390$ group $=16.48, P<0.01 ; \mathrm{t}_{0.20 \mathrm{mg} / \mathrm{kg} \mathrm{sCH} 23390 \text { group }}=6.228, P<0.01 ; \mathrm{t}_{0.50 \mathrm{mg} / \mathrm{kg} \mathrm{sCH} 23390 \text { group }}=10.24, P<0.01$; $\mathrm{t}_{0.02} \mathrm{mg} / \mathrm{kg}$ Raclopride group $=13.91, P<0.01 ; \mathrm{t}_{0.10 \mathrm{mg} / \mathrm{kg} \text { Raclopride group }}=9.565, P<0.01 ; \mathrm{t}_{0.20} \mathrm{mg} / \mathrm{kg}$ Raclopride group $=14.55, P<0.01$; Table 2 and Fig. 7).

However, compared to the number of valid nose pokes in the first three days, there was a slight decrease in the last three days in the Saline group $\left(t_{\text {Saline group }}=2.977, P<0.01\right.$; Table 2 and Fig. 5$)$, and that in the Saline group also remained relatively stable during the last three days of the training period $\left(\mathrm{F}_{\text {Saline }}\right.$ group $=1.028, P=0.3777$; Table 2 and Fig. 7). 
Table 2

The change for valid nose pokes before and after drug self-administration training procedure in every group.

\begin{tabular}{|lllll|}
\hline Group & Day $_{1 \sim 3}$ & Day $_{12 ~ 14}$ & $t$ & $P$ \\
\hline Saline group & $4.095 \pm 0.5385$ & $2.095 \pm 0.4018$ & 2.977 & $<0.01$ \\
\hline Control group & $6.389 \pm 0.9293$ & $29.06 \pm 0.8023$ & 18.46 & $<0.01$ \\
\hline VTA-lesioned group & $7.833 \pm 1.185$ & $26.67 \pm 0.8737$ & 12.79 & $<0.01$ \\
\hline $\mathbf{0 . 0 2} \mathbf{~ m g / k g ~ S C H 2 3 3 9 0 ~ g r o u p ~}$ & $7.429 \pm 0.9400$ & $27.81 \pm 0.8036$ & 16.48 & $<0.01$ \\
\hline $\mathbf{0 . 2 0} \mathbf{~ m g / k g ~ S C H 2 3 3 9 0 ~ g r o u p ~}$ & $15.29 \pm 1.804$ & $29.90 \pm 1.502$ & 6.228 & $<0.01$ \\
\hline $\mathbf{0 . 5 0} \mathbf{~ m g / k g ~ S C H 2 3 3 9 0 ~ g r o u p ~}$ & $9.238 \pm 1.555$ & $31.24 \pm 1.481$ & 10.24 & $<0.01$ \\
\hline $\mathbf{0 . 0 2} \mathbf{~ m g / k g ~ R a c l o p r i d e ~ g r o u p ~}$ & $8.905 \pm 1.005$ & $27.90 \pm 0.9256$ & 13.91 & $<0.01$ \\
\hline $\mathbf{0 . 1 0} \mathbf{~ m g / k g ~ R a c l o p r i d e ~ g r o u p ~}$ & $10.90 \pm 1.499$ & $28.33 \pm 1.036$ & 9.565 & $<0.01$ \\
\hline $\mathbf{0 . 2 0} \mathbf{~ m g / k g ~ R a c l o p r i d e ~ g r o u p ~}$ & $5.762 \pm 0.9333$ & $27.86 \pm 1.198$ & 14.55 & $<0.01$ \\
\hline
\end{tabular}

In addition, we analyzed the rats' behavior between every Cocaine-addicted group and the Saline group. The number of valid nose pokes in the last three days in every Cocaine-addicted group increased compared to that in the Saline group ( $\mathrm{t}_{\text {Control group, Saline group }}=31.38, P<0.01$; $\mathrm{t}_{\mathrm{VTA}}$-lesioned group, Saline

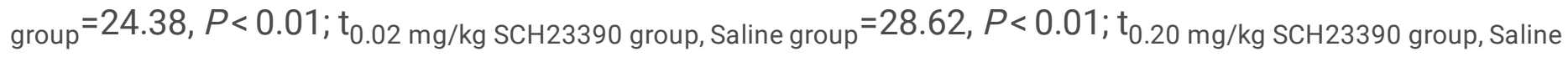
group $=17.88, P<0.01 ; \mathrm{t}_{0.50} \mathrm{mg} / \mathrm{kg} \mathrm{SCH} 23390$ group, Saline group $=18.99, P<0.01 ; \mathrm{t}_{0.02} \mathrm{mg} / \mathrm{kg}$ Raclopride group, Saline

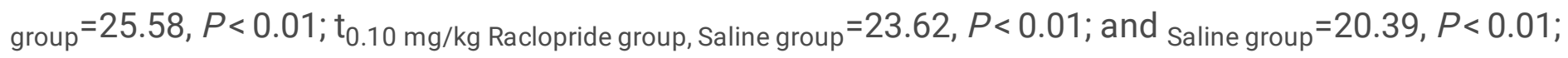
Table 2 and Fig. 8). And there was no significant difference in the number of valid nose pokes in the last three days among every Cocaine-addicted group $(F=1.706, P=0.1111)$, which indicates that every Cocaine-addicted group had effectively established a cocaine self-administration model.

\section{Step 2: We analyzed the rats' behavior during cue-induced cocaine memory reconsolidation in every group.}

After statistical analysis from the same subgroup, the number of "valid" nose pokes showed a significant decrease before and after cue-induced cocaine memory reconsolidation in the following groups $\left(\mathrm{t}_{\text {VTA-lesioned group }}^{\prime}=12.79, P<0.01 ; \mathrm{t}_{0.20 \mathrm{mg} / \mathrm{kg} \mathrm{SCH} 23390 \text { group }}^{\prime}=8.978, P<0.01 ; \mathrm{t}_{0.50 \mathrm{mg} / \mathrm{kg} \mathrm{SCH} 23390}^{\prime}\right.$

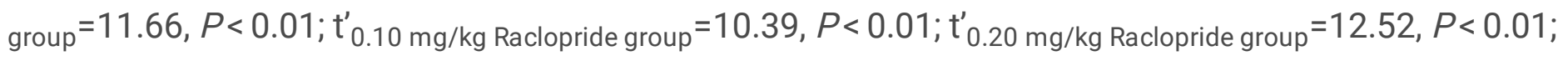
Table 3 and Fig. 7), while there was no significant change in the number of valid nose pokes in Saline, low SCH 23390 and low Raclopride groups ( $\mathrm{t}_{\text {Saline group }}=1.090, P=0.2855 ; \mathrm{t}_{0.02}^{\prime} \mathrm{mg} / \mathrm{kg} \mathrm{sCH} 23390$ group $=1.863, P=0.0738 ; \mathrm{t}_{0.02}^{\prime} \mathrm{mg} / \mathrm{kg}$ Raclopride group $=1.758, P=0.0904 ;$ Table 3 and Fig. 7$)$. Interestingly, the control group showed a significant increase in the number of valid nose pokes $\left(\mathrm{t}^{\prime}\right.$ Control group $=4.221, P<$ 0.01; Table 3 and Fig. 7). 
Table 3

The change for "valid" nose pokes during cue-induced cocaine memory reconsolidation in every group.

\begin{tabular}{|c|c|c|c|c|}
\hline Group & Day $_{12 \sim 14}$ & $\operatorname{Day}_{29}$ & $t^{\prime}$ & $P$ \\
\hline Saline group & $2.095 \pm 0.4018$ & $1.286 \pm 0.4206$ & 1.090 & 0.2855 \\
\hline Control group & $29.06 \pm 0.8023$ & $36.33 \pm 1.801$ & 4.221 & $<0.01$ \\
\hline VTA-lesioned group & $26.67 \pm 0.8737$ & $6.375 \pm 0.7545$ & 12.79 & $<0.01$ \\
\hline $0.02 \mathrm{mg} / \mathrm{kg} \mathrm{SCH} 23390$ group & $27.81 \pm 0.8036$ & $32.43 \pm 3.677$ & 1.863 & 0.0738 \\
\hline $0.20 \mathrm{mg} / \mathrm{kg} \mathrm{SCH} 23390$ group & $29.90 \pm 1.502$ & $6.000 \pm 0.6901$ & 8.978 & $<0.01$ \\
\hline $0.50 \mathrm{mg} / \mathrm{kg} \mathrm{SCH} 23390$ group & $31.24 \pm 1.481$ & $0.8571 \pm 0.3401$ & 11.66 & $<0.01$ \\
\hline 0.02 mg/kg Raclopride group & $27.90 \pm 0.9256$ & $31.57 \pm 2.359$ & 1.758 & 0.0904 \\
\hline 0.10 mg/kg Raclopride group & $28.33 \pm 1.036$ & $9.143 \pm 0.5948$ & 10.39 & $<0.01$ \\
\hline $0.20 \mathrm{mg} / \mathrm{kg}$ Raclopride group & $27.86 \pm 1.198$ & $1.429 \pm 0.3689$ & 12.52 & $<0.01$ \\
\hline
\end{tabular}

Next, we analyzed the rats' behavior between every experimental group and the Control group.

At the begining, Our experimental results showed that the number of "valid" nose pokes before and after cue-induced cocaine memory reconsolidation showed a significant increase in the Control group compared with the Saline group $\left(\mathrm{t}^{\prime}\right.$ Control group, Saline group $=20.41, P<0.01$; Fig. 9).

And further, we found the number of "valid" nose pokes between the VTA-lesioned/high SCH 23390/high raclopride group and the Control group all showed a significant decrease during cue-induced cocaine

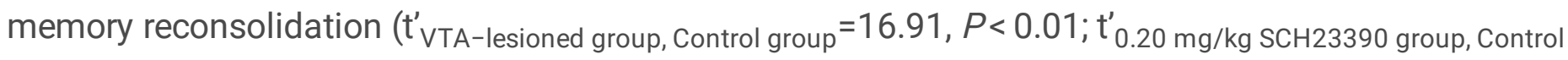

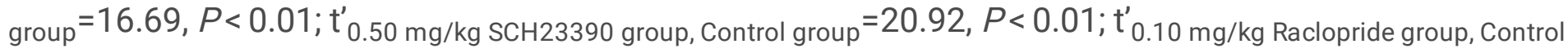
group $=15.30, P<0.01 ; \mathrm{t}^{\prime}{ }_{0.20} \mathrm{mg} / \mathrm{kg}$ Raclopride group, Control group $=20.50, P<0.01 ;$ Fig. 9).

However, there was no significant difference between the low SCH 23390/low raclopride group and the Control group during cue-induced cocaine memory reconsolidation $\left(\mathrm{t}^{\prime}{ }_{0.02} \mathrm{mg} / \mathrm{kg} \mathrm{SCH} 23390\right.$ group, Control group $=0.9026, P=0.3861 ; \mathrm{t}_{0.02}^{\prime} \mathrm{mg} / \mathrm{kg}$ Raclopride group, Control group $=1.560, P=0.1470 ;$ Fig. 9 ).

These data demonstrated that only a certain high concentration of dopamine $D_{1}$ and $D_{2}$ receptor antagonists, or VTA lesions, could effectively disturb subsequent cue-induced cocaine SA-related memory reconsolidation drug-seeking behavior in rats. These results indicate that pharmacological interventions for the dopamine motivation system could effectively disturb subsequent cue-induced drug memory reconsolidation.

\section{Discussion}


In our study, a close correlation between drug (cocaine) and valid nose poke in the presence of drugpaired environmental stimuli was effectively established using the classic drug self-administration model in rats, and drug memory reconsolidation could be strongly reactivated by the drug-paired environmental stimuli alone. Using a biological behavior method, we explored the role of the dopamine system in the cue-induced cocaine memory reconsolidation process. The main results in our study were as follows. First, dopamine played an important role in cue-induced cocaine SA-related memory reconsolidation. Second, pharmacological interventions on the dopamine motivation system could effectively disturb subsequent cue-induced cocaine SA-related memory reconsolidation drug-seeking behavior after reexposure to drug-paired environmental stimuli. Third, only a certain high dose of dopamine $D_{1}$ and $D_{2}$ receptor antagonists, or VTA lesions, could effectively disturb subsequent cue-induced cocaine SA-related memory reconsolidation behavior in rats. The above results strongly indicated that pharmacological interventions on the dopamine motivation system could effectively disturb subsequent cue-induced drug memory reconsolidation.

Dopamine $D_{1}$ and $D_{2}$ receptors are critical for learning and memory, as well as reward and reinforcement(Fraser et al., 2016; Goldman-Rakic, Castner, Svensson, Siever, \& Williams, 2004; Xu et al., 2009). A related study reported that 6-hydroxydopamine (6-OHDA) lesions to cells in the ventral tegmental area (VTA) could affect cocaine intake and disrupt cocaine self-administration(Roberts \& Koob, 1982). This result is consistent with our results. Above all, in our experimental findings, dopamine played an important role in cue-induced cocaine SA-related memory reconsolidation. In the CPP (conditioned place preference) model, interventions targeting certain kinds of receptors, such as glutamatergic and dopaminergic receptors, could lead to the absence of late CPP memory(Brown et al., 2008; Y. Li et al., 2016; Otis \& Mueller, 2011; Spina et al., 2006). Many related experiments showed that the repeated systemic administration of SCH23390 could prevent cocaine CPP(Baker, Fuchs, Specio, Khroyan, \& Neisewander, 1998; Cervo \& Samanin, 1995). Our previous findings confirmed that bilateral NAc-shell infusion of $\mathrm{SCH} 23390$ (dopamine $\mathrm{D}_{1}$ receptor antagonist) could disturb $\mathrm{CPP}$ related behavior during cocaine memory reconsolidation(Y Li et al., 2016). Many previous studies showed that dopamine $D_{1}$ receptors can modulate IEG-encoded protein expression via the cyclic adenosine monophosphate (cAMP)-protein kinase A (PKA)-ERK-CREB pathway(Goto, Otani, \& Grace, 2007; Y. Li et al., 2016; David W Self, 2004). Additionally, many studies demonstrated that dopamine $D_{1}$ receptors are necessary for the induction of long-term potentiation (LTP) and long-term depression (LTD) both in vitro and in vivo(Centonze et al., 2003; Kerr \& Wickens, 2001; Shen, Flajolet, Greengard, \& Surmeier, 2008). The activation of dopamine $D_{1}$ receptors has been shown to enhance cocaine CPP(Kreitzer \& Berke, 2011; Lobo \& Nestler, 2011). As a result, dopamine $D_{1}$ receptor antagonists could effectively disturb subsequent cue-induced cocaine SA-related memory reconsolidation drug-seeking behavior after re-exposure to drugpaired environmental stimuli.

Numerous studies have verified that cocaine-seeking behavior can be reinstated following the administration of dopamine $\mathrm{D}_{2}$ receptor agonists (De Vries, 2002; D. W. Self, Barnhart, Lehman, \& Nestler, 1996), while cocaine priming-induced drug-seeking behavior was attenuated following the administration 
of a dopamine $D_{2}$ receptor antagonist (Khroyan, Barrett-Larimore, Rowlett, \& Spealman, 2000). Previous studies showed that raclopride (dopamine $\mathrm{D}_{2}$ antagonist, s.c.) could completely prevent drug-seeking behavior induced by the reintroduction of cocaine-paired stimuli(Cervo, Carnovali, Stark, \& Mennini, 2003; Froger-Colleaux \& Castagne, 2016). This finding is the same as our results. The above results showed that dopamine $\mathrm{D}_{2}$ receptors could affect subsequent cue-induced cocaine SA-related memory reconsolidation drug-seeking behavior after re-exposure to drug-paired environmental stimuli.

However, conditioned place preference for psychostimulants was reduced by the activation of $D_{2}$ receptors (Kreitzer \& Berke, 2011; Lobo \& Nestler, 2011) and increased by their inactivation(Ferguson et al., 2011). Moreover, $D_{2}$ inhibition increased motivation for cocaine, whereas the activation of $D_{2}$ receptors reduced cocaine self-administration(Bock et al., 2013). Dopamine mainly includes $D_{1}$ and $D_{2}$ two subtype receptors, both of which are slow metabotropic receptors coupled with G-proteins. $D_{1}$ receptors activation increases intracellular cAMP, while $\mathrm{D}_{2}$ receptors activation decreases intracellular cAMP (Goto et al., 2007). Therefore, it is theoretically possible that two dopamine receptors may have the opposite effect by inducing different forms of neuronal plasticity, leading to subsequent disruption of learning and memory functions (Floresco \& Phillips, 2001; Nasehi et al., 2010). However, in our experiment, we did not find this phenomenon. We previously demonstrated that a certain concentration of $\mathrm{SCH} 23390$ (dopamine $\mathrm{D}_{1}$ receptor antagonist) could disrupt cue-induced cocaine memory reconsolidation after re-exposure to cocaine-associated environmental cues in a cocaine-induced CPP model for rats but that raclopride (dopamine $\mathrm{D}_{2}$ receptor antagonist) could not(Y Li et al., 2016). It is possible that there are different mechanisms for CPP and SA animal models of drug addiction. Several previous studies have shown that MK-801 (an NMDA receptor antagonist) can disrupt the reconsolidation of cocaine-related memory in the CPP model but not in the SA model in rats(Brown et al., 2008). Thus, further investigation is needed to explore the mechanism to clarify the molecular network involved in addictive memory reconsolidation and the specific molecular mechanism underlying drug addiction( $\mathrm{Y}$. Li et al., 2016).

In summary, according to our data, the dopamine system could be the main site of reward circuit activation in the process of cue-induced drug memory reconsolidation, and this result may provide a theoretical basis for the clinical development of interventions focused on a critical target-dopamine system for the purpose of treating drug addiction. Furthermore, our results showed that dopamine $D_{1}$ and $D_{2}$ receptors are key regulators of dopamine system function during the reconsolidation addictive memory process. Memory reconsolidation theory suggests that it may be a key stage in the treatment of pathological memory function. Importantly, dopamine $D_{1}$ and $D_{2}$ receptors may represent pharmacological targets for the treatment of drug addiction with therapies that interfere with drug memory reconsolidation.

\section{Declarations}


This project was supported by the National Natural Science Foundation of China (No. 81671366 and 81971244, awarded to Xue-lian Wang) and Science and Technology Innovation Foundation of Tangdu Hospital, the Fourth Military Medical University (No. 2017LCYJ002, awarded to Xue-lian Wang).

\section{Authors' contribution}

Yang Li, Nan Li and Liang Qu equally contributed to this work including animal surgeries, drug selfadministration training, data collection, immunohistochemical staining, manuscript draft and so on.

Xue-lian Wang was involved in study concept and design, and also provided funding.

Shun-nan Ge helped design the primary study, provided advice on the data analysis, and edited the manuscript.

Xin Wang and Ping Wang processed data and conducted literature searches.

Jian Fu, Yu-kun Chen and Jian-cai Wang provided advice on the data analysis and implemented statistical analysis.

All authors read and approved the final manuscript.

\section{Conflicts of interest}

The authors have no conflicts of interest to declare.

\section{Statement}

All animal procedures in our experiments were consistent with the guidelines of the Committee for Animal Care and Use (No. TDLL2018-03-180, Tangdu Hospital, the Fourth Military Medical University, Xi'an, Shaanxi, China). And the experimental protocols were approved by the Committee for Animal Care and Use of Tangdu Hospital, the Fourth Military Medical University. In addition, all methods in our experiment are reported in accordance with ARRIVE guidelines.

\section{References}

1. Baker, D. A., Fuchs, R. A., Specio, S. E., Khroyan, T. V., \& Neisewander, J. L. (1998). Effects of intraaccumbens administration of $\mathrm{SCH}-23390$ on cocaine-induced locomotion and conditioned place preference. Synapse, 30(2), 181-193. doi:10.1002/(SICI)1098-2396(199810)30:2<181::AIDSYN8>3.0.CO;2-8

2. Belliotti, T. R. et al. A series of 6- and 7-piperazinyl- and -piperidinylmethylbenzoxazinones with dopamine D4 antagonist activity: discovery of a potential atypical antipsychotic agent. J Med Chem. 42 (25), 5181-5187 https://doi.org/10.1021/jm990277d (1999). 
3. Bock, R. et al. Strengthening the accumbal indirect pathway promotes resilience to compulsive cocaine use. Nat Neurosci. 16 (5), 632-638 https://doi.org/10.1038/nn.3369 (2013).

4. Brown, T. E., Lee, B. R. \& Sorg, B. A. The NMDA antagonist MK-801 disrupts reconsolidation of a cocaine-associated memory for conditioned place preference but not for self-administration in rats. Learn Mem. 15 (12), 857-865 (2008).

5. Centonze, D. et al. Distinct roles of D1 and D5 dopamine receptors in motor activity and striatal synaptic plasticity. J Neurosci. 23 (24), 8506-8512 https://doi.org/10.1523/jneurosci.23-2408506.2003 (2003).

6. Cervo, L., Carnovali, F., Stark, J. A. \& Mennini, T. Cocaine-seeking behavior in response to drugassociated stimuli in rats: involvement of D3 and D2 dopamine receptors. Neuropsychopharmacology. 28 (6), 1150-1159 https://doi.org/10.1038/sj.npp.1300169 (2003).

7. Cervo, L. \& Samanin, R. Effects of dopaminergic and glutamatergic receptor antagonists on the acquisition and expression of cocaine conditioning place preference. Brain Res. 673 (2), 242-250 https://doi.org/10.1016/0006-8993(94)01420-m (1995).

8. Chauvet, C., Lardeux, V., Goldberg, S. R., Jaber, M. \& Solinas, M. Environmental enrichment reduces cocaine seeking and reinstatement induced by cues and stress but not by cocaine. Neuropsychopharmacology. 34 (13), 2767-2778 https://doi.org/10.1038/npp.2009.127 (2009).

9. Chen, W. et al. Role of Dopamine Signaling in Drug Addiction. Curr Top Med Chem. 17 (21), 24402455 https://doi.org/10.2174/1568026617666170504100642 (2017).

10. Childress, A. R. et al. Limbic activation during cue-induced cocaine craving. Am J Psychiatry. 156 (1), 11-18 https://doi.org/10.1176/ajp.156.1.11 (1999).

11. De Vries, T. Relapse to Cocaine- and Heroin-Seeking Behavior Mediated by Dopamine D2 Receptors Is Time-Dependent and Associated with Behavioral Sensitization. Neuropsychopharmacology. 26 (1), 18-26 https://doi.org/10.1016/s0893-133x(01)00293-7 (2002).

12. Diergaarde, L., Schoffelmeer, A. N. \& De Vries, T. J. Pharmacological manipulation of memory reconsolidation: towards a novel treatment of pathogenic memories. Eur J Pharmacol. 585 (2-3), 453-457 https://doi.org/10.1016/j.ejphar.2008.03.010 (2008).

13. Drugs, U. N. O. o., \& Crime. (2010). World drug report 2010:United Nations Publications.

14. Everitt, B. J., Giuliano, C. \& Belin, D. Addictive behaviour in experimental animals: prospects for translation. Philos Trans R Soc Lond B Biol Sci. 373 (1742), https://doi.org/10.1098/rstb.2017.0027 (2018).

15. Ferguson, S. M. et al. Transient neuronal inhibition reveals opposing roles of indirect and direct pathways in sensitization. Nat Neurosci. 14 (1), 22-24 https://doi.org/10.1038/nn.2703 (2011).

16. Floresco, S. B. \& Phillips, A. G. Delay-dependent modulation of memory retrieval by infusion of a

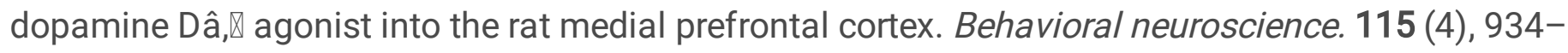
939 https://doi.org/10.1037/0735-7044.115.4.934 (2001).

17. Fraser, K. M., Haight, J. L., Gardner, E. L. \& Flagel, S. B. Examining the role of dopamine D2 and D3 receptors in Pavlovian conditioned approach behaviors. Behav Brain Res. 305, 87-99 
https://doi.org/10.1016/j.bbr.2016.02.022 (2016).

18. Froger-Colleaux, C. \& Castagne, V. Effects of baclofen and raclopride on reinstatement of cocaine self-administration in the rat. Eur J Pharmacol. 777, 147-155 https://doi.org/10.1016/j.ejphar.2016.03.008 (2016).

19. Gasbarri, A., Sulli, A. \& Packard, M. G. The dopaminergic mesencephalic projections to the hippocampal formation in the rat. Prog Neuropsychopharmacol Biol Psychiatry. 21 (1), 1-22 https://doi.org/10.1016/s0278-5846(96)00157-1 (1997).

20. Gauthier, J. M. et al. Environmental enrichment facilitates cocaine-cue extinction, deters reacquisition of cocaine self-administration and alters AMPAR GluA1 expression and phosphorylation. Addict Biol. 22 (1), 152-162 https://doi.org/10.1111/adb.12313 (2017).

21. Goldman-Rakic, P. S., Castner, S. A., Svensson, T. H., Siever, L. J. \& Williams, G. V. Targeting the dopamine D1 receptor in schizophrenia: insights for cognitive dysfunction. Psychopharmacology (Berl). 174 (1), 3-16 https://doi.org/10.1007/s00213-004-1793-y (2004).

22. Goto, Y., Otani, S. \& Grace, A. A. The Yin and Yang of dopamine release: a new perspective. Neuropharmacology. 53 (5), 583-587 https://doi.org/10.1016/j.neuropharm.2007.07.007 (2007).

23. Howard, C. D., Li, H., Geddes, C. E. \& Jin, X. Dynamic Nigrostriatal Dopamine Biases Action Selection. Neuron. 93 (6), 1436-14501438 https://doi.org/10.1016/j.neuron.2017.02.029 (2017).

24. Hyman, S. E., Malenka, R. C. \& Nestler, E. J. Neural mechanisms of addiction: the role of rewardrelated learning and memory. Annu Rev Neurosci. 29, 565-598 https://doi.org/10.1146/annurev.neuro.29.051605.113009 (2006).

25. Kerr, J. N. \& Wickens, J. R. Dopamine D-1/D-5 receptor activation is required for long-term potentiation in the rat neostriatum in vitro. J Neurophysiol. 85 (1), 117-124 https://doi.org/10.1152/jn.2001.85.1.117 (2001).

26. Khroyan, T. V., Barrett-Larimore, R. L., Rowlett, J. K. \& Spealman, R. D. (2000). Dopamine D1- and D2like receptor mechanisms in relapse to cocaine-seeking behavior: effects of selective antagonists and agonists. J Pharmacol Exp Ther, 294(2), 680-687. Retrieved from https://www.ncbi.nlm.nih.gov/pubmed/10900248

27. Koob, G. \& Volkow, N. Neurocircuitry of addiction. Neuropsycopharmacology. 35, 217-238 (2010).

28. Kreitzer, A. C. \& Berke, J. D. Investigating striatal function through cell-type-specific manipulations. Neuroscience. 198, 19-26 https://doi.org/10.1016/j.neuroscience.2011.08.018 (2011).

29. Li, Y. et al. (2016). NMDA and dopamine D1 receptors within NAc-shell regulate IEG proteins expression in reward circuit during cocaine memory reconsolidation. Neuroscience, 315, 45-69. Retrieved from https://ac.els-cdn.com/S0306452215010623/1-s2.0-S0306452215010623-main.pdf? _tid=0dd74712-6bb7-40cf-8cdf3a4d81b9b160\&acdnat=1545189469_cc533582d6159ed8009807da336db936

30. Li, Y. et al. NMDA and dopamine D1 receptors within NAc-shell regulate IEG proteins expression in reward circuit during cocaine memory reconsolidation. Neuroscience. 315, 45-69 https://doi.org/10.1016/j.neuroscience.2015.11.063 (2016). 
31. Li, Y. et al. The NAc lesions disrupted the hippocampus-mPFC theta coherence during intravenous cocaine administration in rats. Neurosci Lett. 729, 134986 https://doi.org/10.1016/j.neulet.2020.134986 (2020).

32. Lobo, M. K. \& Nestler, E. J. The striatal balancing act in drug addiction: distinct roles of direct and indirect pathway medium spiny neurons. Front Neuroanat. 5, 41 https://doi.org/10.3389/fnana.2011.00041 (2011).

33. Nasehi, M. et al. Involvement of dopamine D1/D2 receptors on harmane-induced amnesia in the step-down passive avoidance test. Eur J Pharmacol. 634 (1-3), 77-83 https://doi.org/10.1016/j.ejphar.2010.02.027 (2010).

34. Otis, J. M. \& Mueller, D. Inhibition of beta-adrenergic receptors induces a persistent deficit in retrieval of a cocaine-associated memory providing protection against reinstatement. Neuropsychopharmacology. 36 (9), 1912-1920 https://doi.org/10.1038/npp.2011.77 (2011).

35. Roberts, D. C. \& Koob, G. F. Disruption of cocaine self-administration following 6-hydroxydopamine lesions of the ventral tegmental area in rats. Pharmacol Biochem Behav. 17 (5), 901-904 https://doi.org/10.1016/0091-3057(82)90469-5 (1982).

36. Sale, A., Berardi, N. \& Maffei, L. Environment and brain plasticity: towards an endogenous pharmacotherapy. Physiol Rev. 94 (1), 189-234 https://doi.org/10.1152/physrev.00036.2012 (2014).

37. Self, D. W. (2004). Regulation of drug-taking and-seeking behaviors by neuroadaptations in the mesolimbic dopamine system. Neuropharmacology, 47, 242-255. Retrieved from https://ac.elscdn.com/S0028390804001972/1-s2.0-S0028390804001972-main.pdf?_tid=cbfd4b61-8c4c-4ba8bdc8-dfe939ec2f25\&acdnat=1545189329_54bbbb2248fd3cc4f4011f51a64896d1

38. Self, D. W., Barnhart, W. J., Lehman, D. A. \& Nestler, E. J. Opposite modulation of cocaine-seeking behavior by D1- and D2-like dopamine receptor agonists. Science. 271 (5255), 1586-1589 https://doi.org/10.1126/science.271.5255.1586 (1996).

39. Shen, W., Flajolet, M., Greengard, P. \& Surmeier, D. J. Dichotomous dopaminergic control of striatal synaptic plasticity. Science. 321 (5890), 848-851 https://doi.org/10.1126/science.1160575 (2008).

40. Smythies, J. Section II. The dopamine system. Int Rev Neurobiol. 64, 123-172 https://doi.org/10.1016/S0074-7742(05)64002-0 (2005).

41. Spina, L., Fenu, S., Longoni, R., Rivas, E. \& Di Chiara, G. (2006). Nicotine-conditioned single-trial place preference: selective role of nucleus accumbens shell dopamine $D 1$ receptors in acquisition. Psychopharmacology (Berl), 184(3-4), 447-455. Retrieved from https://link.springer.com/article

42. Thiel, K. J. et al. Environmental enrichment counters cocaine abstinence-induced stress and brain reactivity to cocaine cues but fails to prevent the incubation effect. Addict Biol. 17 (2), 365-377 https://doi.org/10.1111/j.1369-1600.2011.00358.x (2012).

43. Thiel, K. J., Sanabria, F., Pentkowski, N. S. \& Neisewander, J. L. Anti-craving effects of environmental enrichment. Int J Neuropsychopharmacol. 12 (9), 1151-1156 https://doi.org/10.1017/S1461145709990472 (2009). 
44. Torregrossa, M. M. \& Taylor, J. R. Prog Brain Res (Vol 223pp. 91-113(Elsevier, 2016). Neuroscience of learning and memory for addiction medicine: from habit formation to memory reconsolidation

45. van Praag, H., Kempermann, G. \& Gage, F. H. Neural consequences of environmental enrichment. Nat Rev Neurosci. 1 (3), 191-198 https://doi.org/10.1038/35044558 (2000).

46. Volkow, N. D., Wise, R. A. \& Baler, R. The dopamine motive system: implications for drug and food addiction. Nat Rev Neurosci. 18 (12), 741-752 https://doi.org/10.1038/nrn.2017.130 (2017).

47. Wahlstrom, D., White, T. \& Luciana, M. Neurobehavioral evidence for changes in dopamine system activity during adolescence. Neurosci Biobehav Rev. 34 (5), 631-648 https://doi.org/10.1016/j.neubiorev.2009.12.007 (2010).

48. Wise, R. A. Roles for nigrostriatal-not just mesocorticolimbic-dopamine in reward and addiction. Trends Neurosci. 32 (10), 517-524 https://doi.org/10.1016/j.tins.2009.06.004 (2009).

49. Xu, T. X. et al. Hyperdopaminergic Tone Erodes Prefrontal Long-Term Potential via a D2 ReceptorOperated Protein Phosphatase Gate. Journal of Neuroscience. 29 (45), 14086-14099 https://doi.org/10.1523/jneurosci.0974-09.2009 (2009).

50. Yager, L. M., Garcia, A. F., Wunsch, A. M. \& Ferguson, S. M. The ins and outs of the striatum: role in drug addiction. Neuroscience. 301, 529-541 https://doi.org/10.1016/j.neuroscience.2015.06.033 (2015).

51. Zhang, F. et al. Direct voltammetric specific recognition of dopamine using Allll-DA complexes at the hanging mercury drop electrode. Anal Sci. 23 (11), 1325-1329 https://doi.org/10.2116/analsci.23.1325 (2007).

\section{Figures}

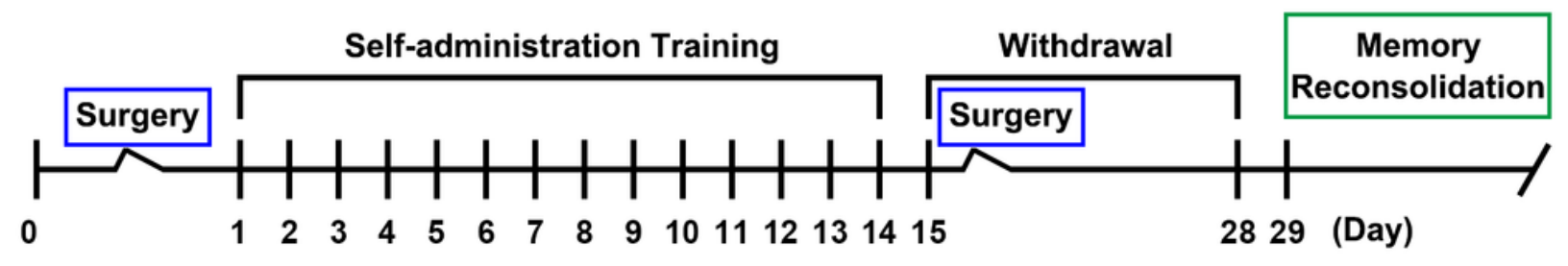

\section{Figure 1}

The experimental process. 

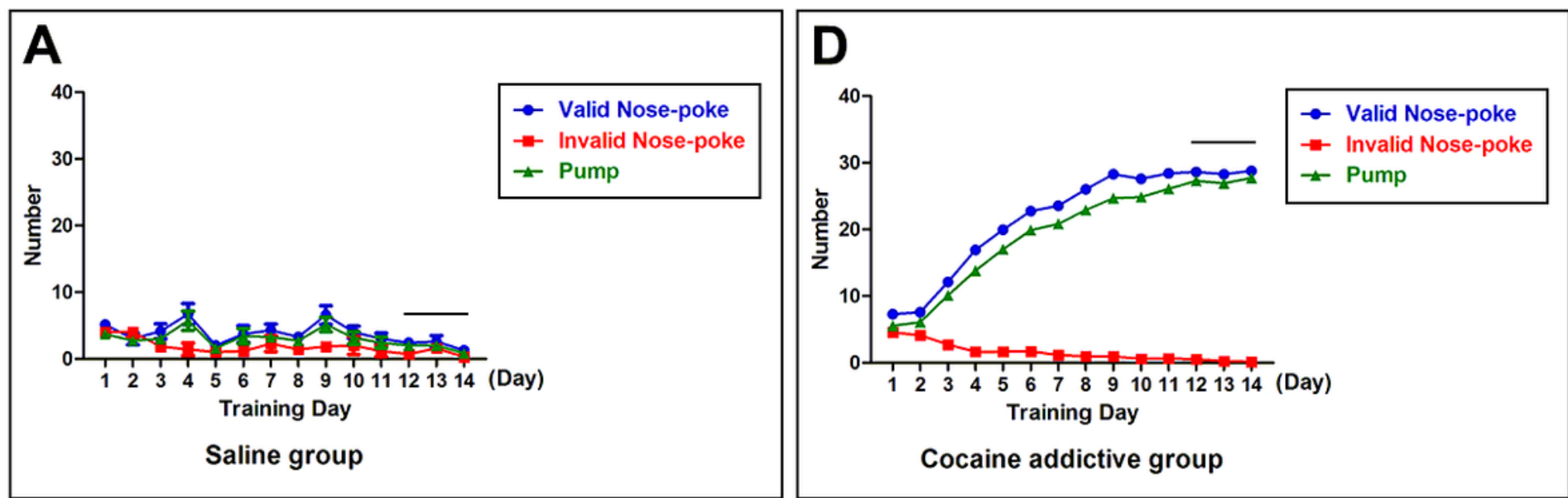

\section{B}

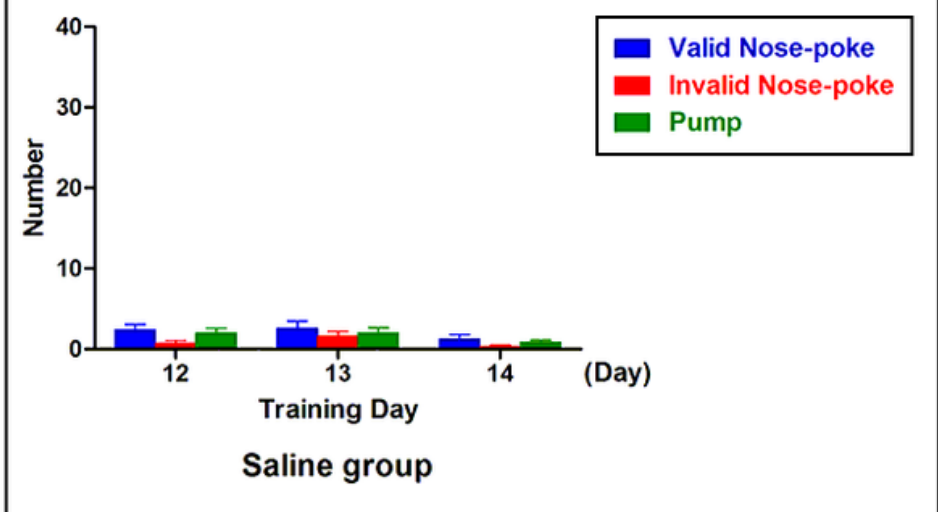

\section{C}

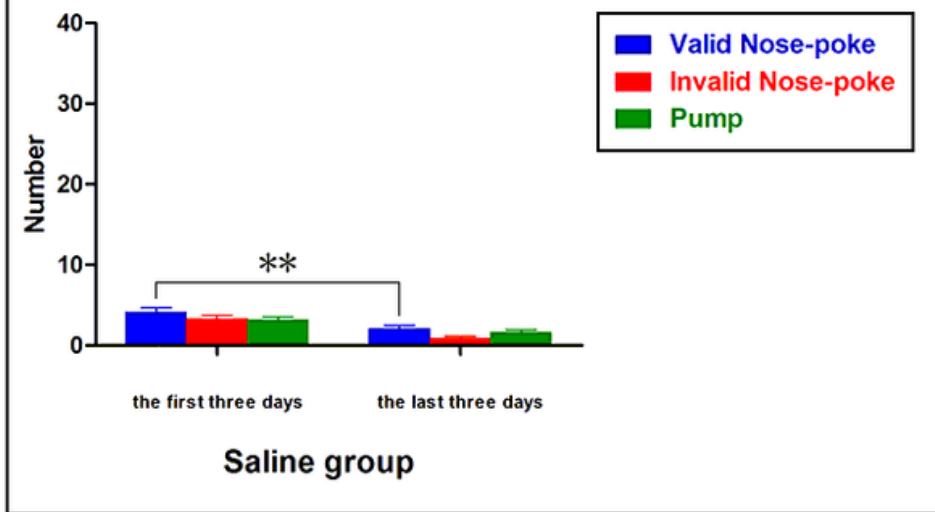

\section{$\mathbf{E}$}

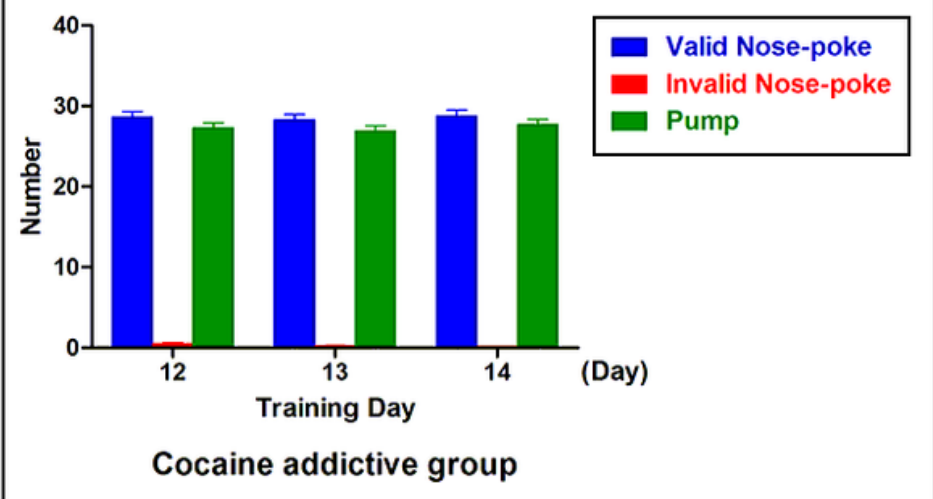

$\mathbf{F}$

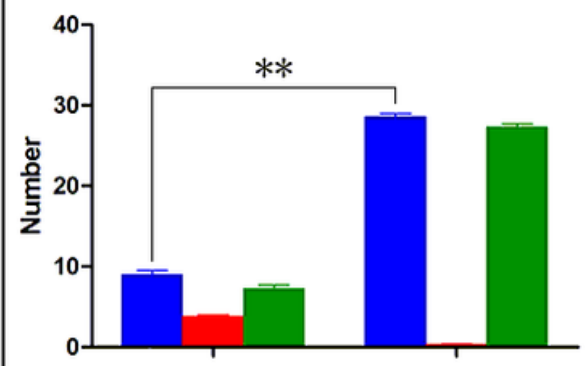

Valid Nose-poke Invalid Nose-poke Pump

\section{Figure 2}

The cocaine self-administration training procedure ( $A$ and $D)$. Compared to the first three days, the number of valid nose poke for the last three days in Cocaine-addicted group increased significantly (Day1 3: $8.994 \pm 0.4945$, Day12 14: $28.55 \pm 0.3998$, tCocaine-addictive group=30.76, $P<0.01$. $(F)$ ) during cocaine SA training period and kept relatively stable during the last three days of training period (FCocaine-addicted group $=0.1244, P=0.8831$. (E)). However, there was a little decreasing for that in Saline group (Day1 3: 4.095 \pm 0.5385, Day12 14: $2.095 \pm 0.4018$, tSaline group=2.977, $P<0.01$. (C)), and the 
number of valid nose pokes reached a relatively stable level during the last three days of training period (FSaline group=1.028, $\mathrm{P}=0.3777$. (B)).
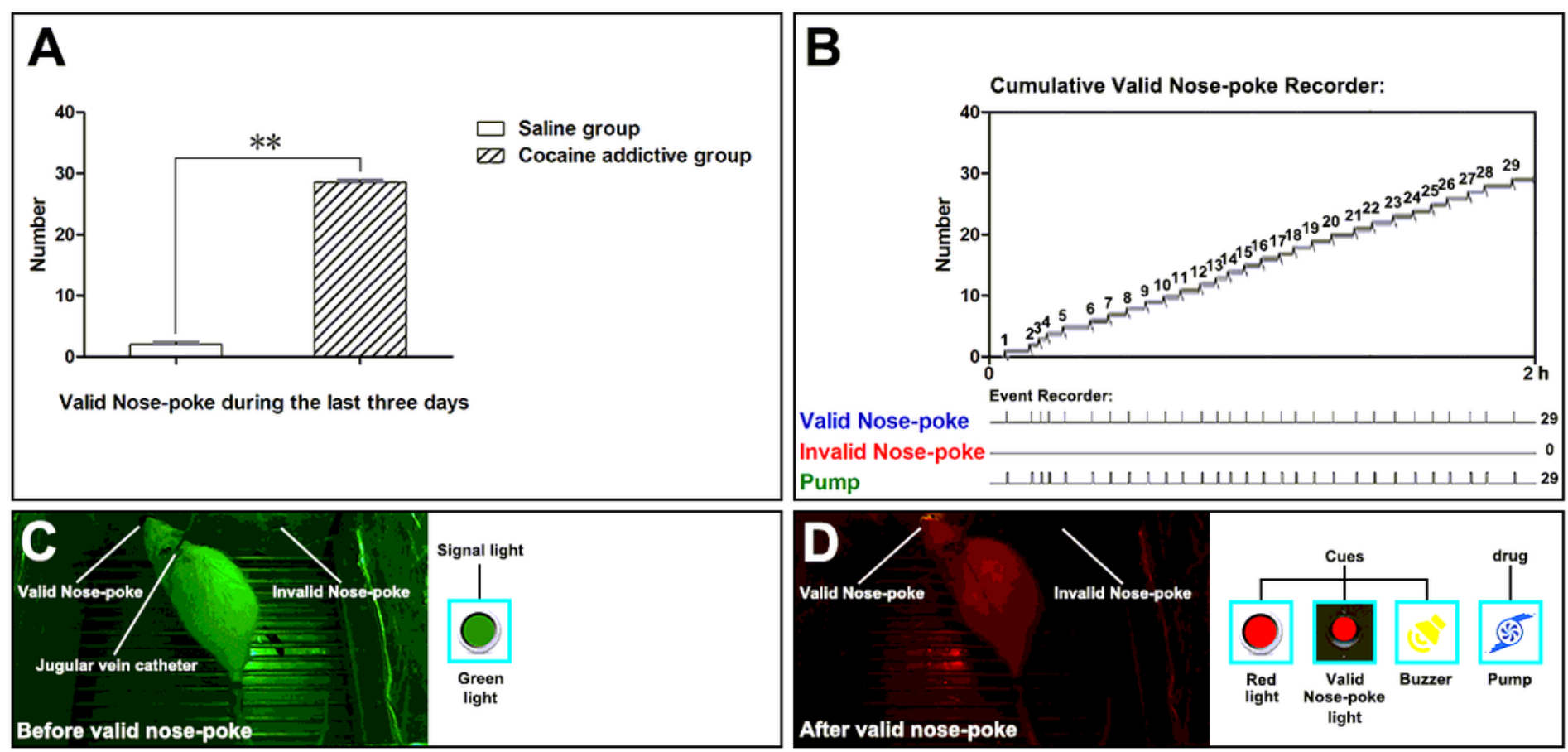

\section{Figure 3}

A. The number of valid nose pokes for the last three days between Cocaine-addicted group and Saline group was significant difference (Day12 14 in Saline group: $2.095 \pm 0.4018$, Day12 14 in Cocaineaddicted group: $28.55 \pm 0.3998$, tCocaine-addicted group, Saline group=23.17, $\mathrm{P}<0.01)$. B. The original recording of the experimental rat's behavioral events. The drug self-administration training lasted $2 \mathrm{~h}$ per day, and the number of nose pokes (valid nose poke and invalid nose poke) and the number of pump were all recorded. C and D. The comparison before and after valid nose poke for the experimental rat. Before valid nose poke, only green light is on $(C)$. When the experimental rat finished a valid nose poke, the system will pump drug once ( $T=1.25 \mathrm{~s}, \mathrm{v}=1.60 \mathrm{~mL} / \mathrm{min})$, accompanied with several changes in environmental cues such as signal lights (Green light is off, and red light is on for $20 \mathrm{~s}$ ), valid nose poke light ( $T=20 \mathrm{~s}$ ), and sound (buzzer, $T=1.25 \mathrm{~s}$ ) (D). SA: Self-administration. Data were presented as means \pm SEM, **P<0.01. 

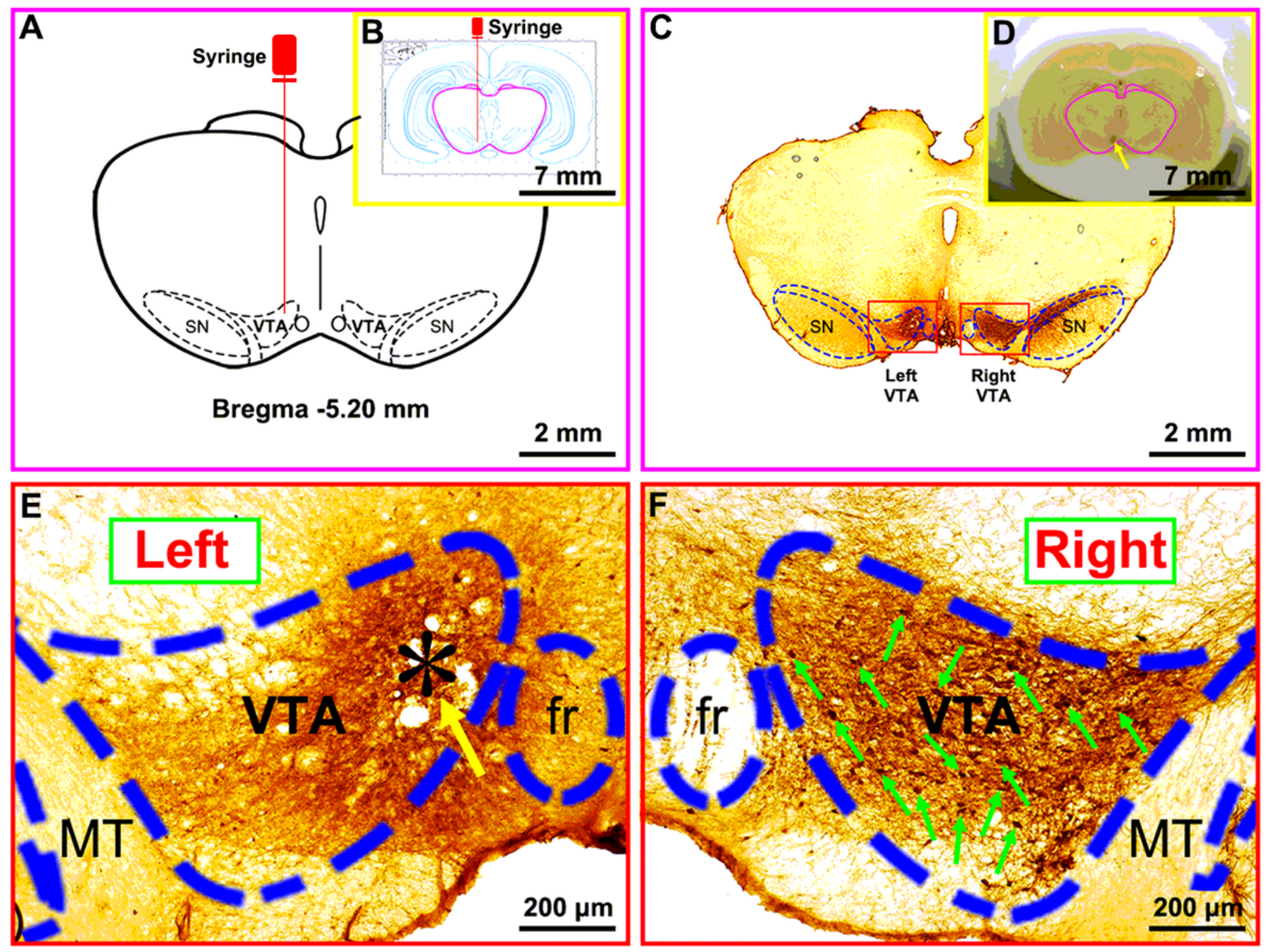

Figure 4

The location of VTA lesion. The figure "A" and "B" were coronal schematic diagrams in the VTA level (Bregma $-5.20 \mathrm{~mm}$ ). The figure " $D$ " was a coronal real diagram in the VTA level. The figure " $C$ " was the coronal real diagram in the VTA level by TH-immunohistochemical staining. The two framed areas in " $\mathrm{C}$ " were magnified in " $E$ " and " $F$ ", respectively. The yellow arrows showed the injection site of 6-OHDA by a 1 $\mu \mathrm{L}$ syringe. " $*$ " presented the tip of syringe. The Green arrows showed many dopamine neurons labelled by TH. There was almost no dopamine neuron labelled by TH on the left side, although a lot of dopamine neurons labelled by TH existed in the right side. 6-OHDA: 6-hydroxydopamine; TH: tyrosine hydroxylase; VTA: ventral tegmental area; MT: medial terminal nucleus of the accessory optic tract; fr: fasciculus retroflexus. Scale bar could be seen in the corresponding figures, respectively. 

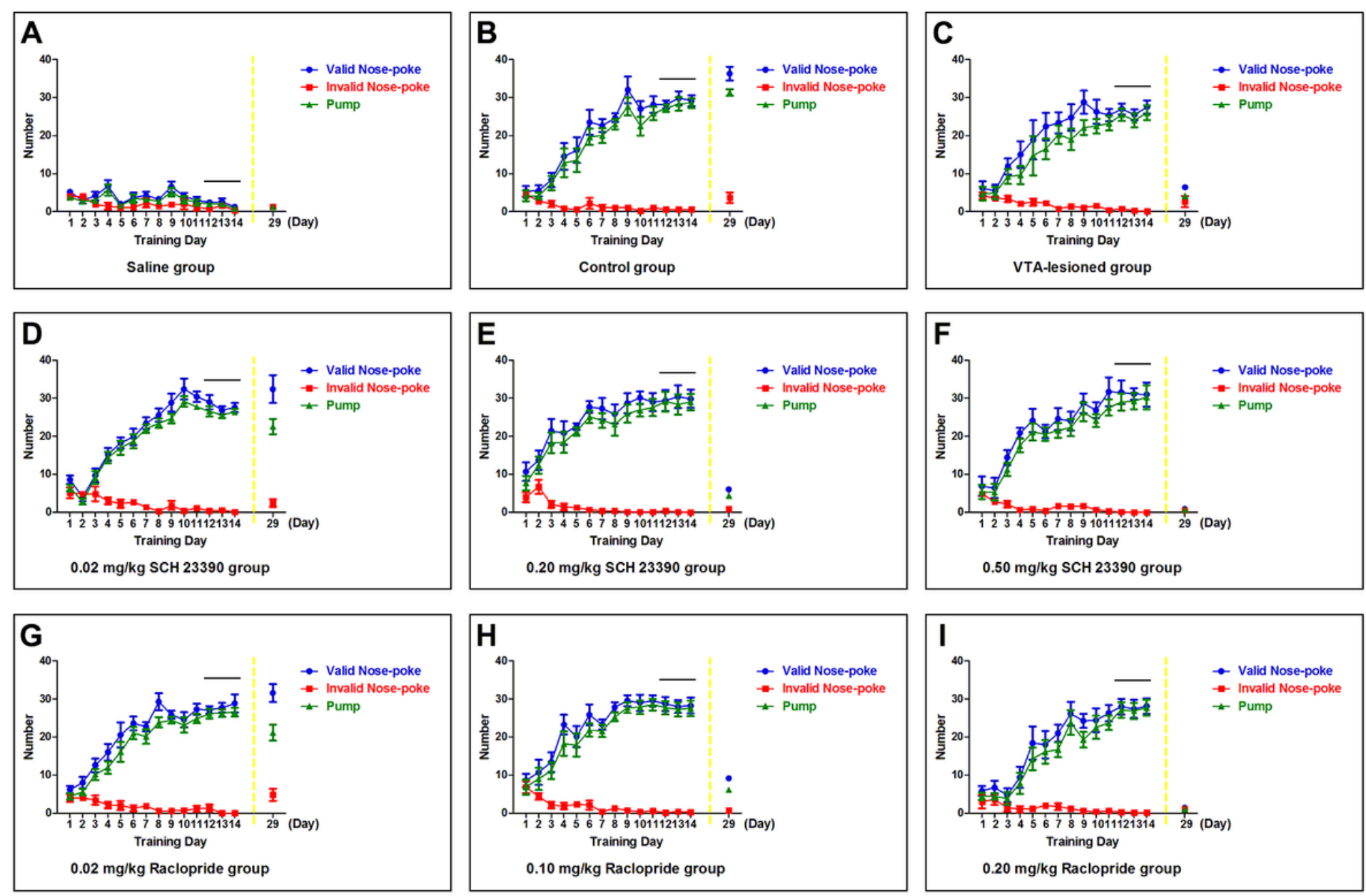

\section{Figure 5}

The cocaine self-administration training procedure in every subgroup. The number of valid nose poke in every Cocaine-addicted group (Control group, VTA-lesioned group, $0.02 \mathrm{mg} / \mathrm{kg} \mathrm{SCH} 23390$ group, 0.20 $\mathrm{mg} / \mathrm{kg} \mathrm{SCH} 23390$ group, 0.50 mg/kg SCH 23390 group, 0.02 mg/kg Raclopride group, $0.10 \mathrm{mg} / \mathrm{kg}$ Raclopride group and $0.20 \mathrm{mg} / \mathrm{kg}$ Raclopride group) increased significantly during cocaine SA training period and kept relatively stable during the last three days of training period. However, there was a little decreasing for that in Saline group and the number of valid nose poke reached a relatively stable level during the last three days of training period. Data were presented as means \pm SEM. 

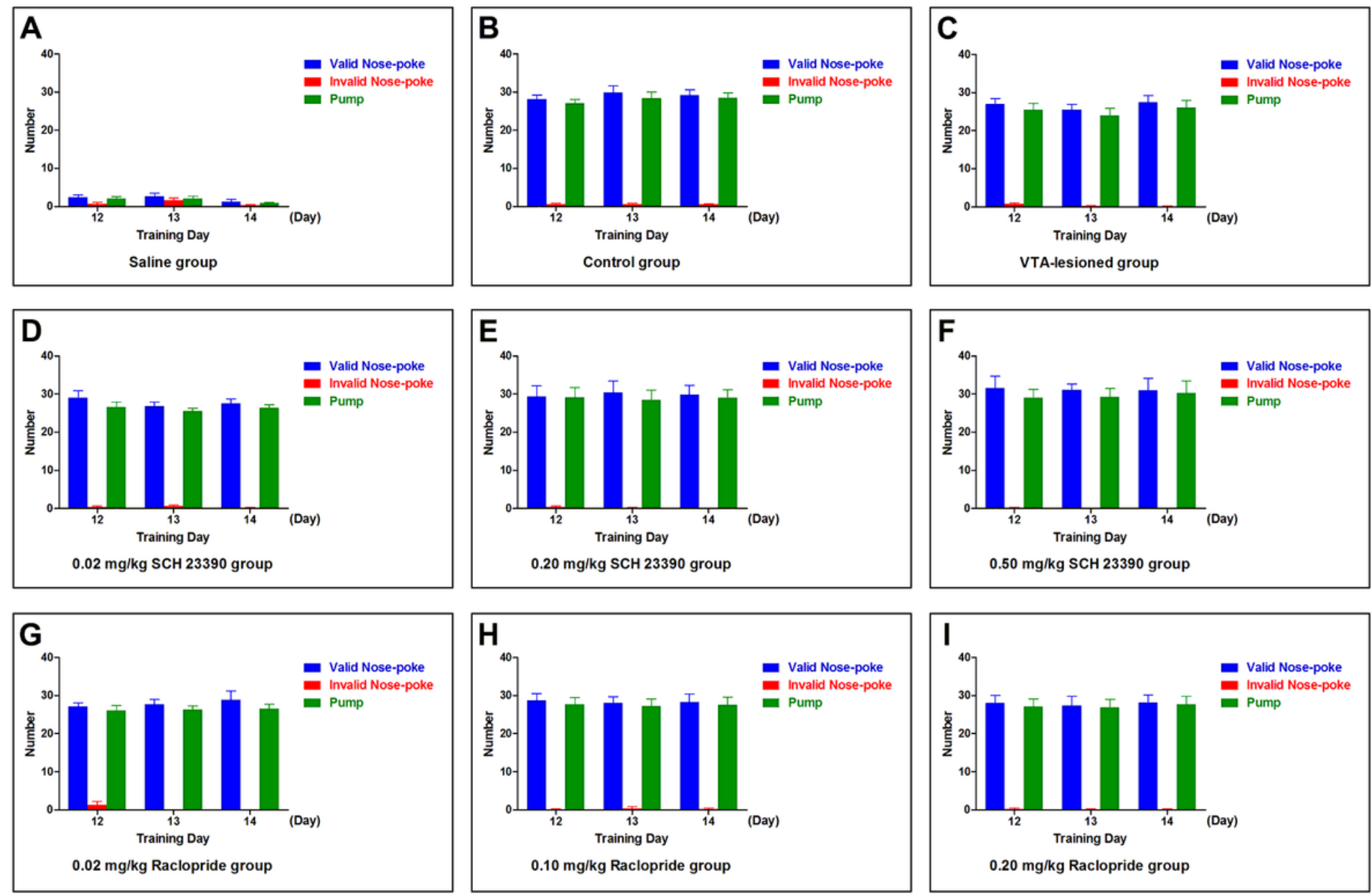

Figure 6

The number of valid nose poke for the last three days in every Cocaine-addicted group reached a relatively stable level during the last three days of training period (FControl group $=0.3360, P=0.7199$; FVTA-lesioned group $=0.4505, P=0.6433 ; F 0.02 \mathrm{mg} / \mathrm{kg} \mathrm{SCH} 23390$ group $=0.5892, P=0.5651 ; \mathrm{F} 0.20 \mathrm{mg} / \mathrm{kg}$ $\mathrm{SCH} 23390$ group $=0.03359, \mathrm{P}=0.9670 ; \mathrm{F} 0.50 \mathrm{mg} / \mathrm{kg} \mathrm{SCH} 23390$ group $=0.01210, \mathrm{P}=0.9880 ; \mathrm{F} 0.02 \mathrm{mg} / \mathrm{kg}$ Raclopride group $=0.2750, P=0.7627 ; F 0.10 \mathrm{mg} / \mathrm{kg}$ Raclopride group $=0.03628, P=0.9644 ; F 0.20 \mathrm{mg} / \mathrm{kg}$ Raclopride group $=0.02997, P=0.9705)$. And that in Saline group also kept relatively stable during the last three days of training period (FSaline group $=1.028, P=0.3777$ ). Data were presented as means $\pm S E M$, $\star * P<0.01$. 

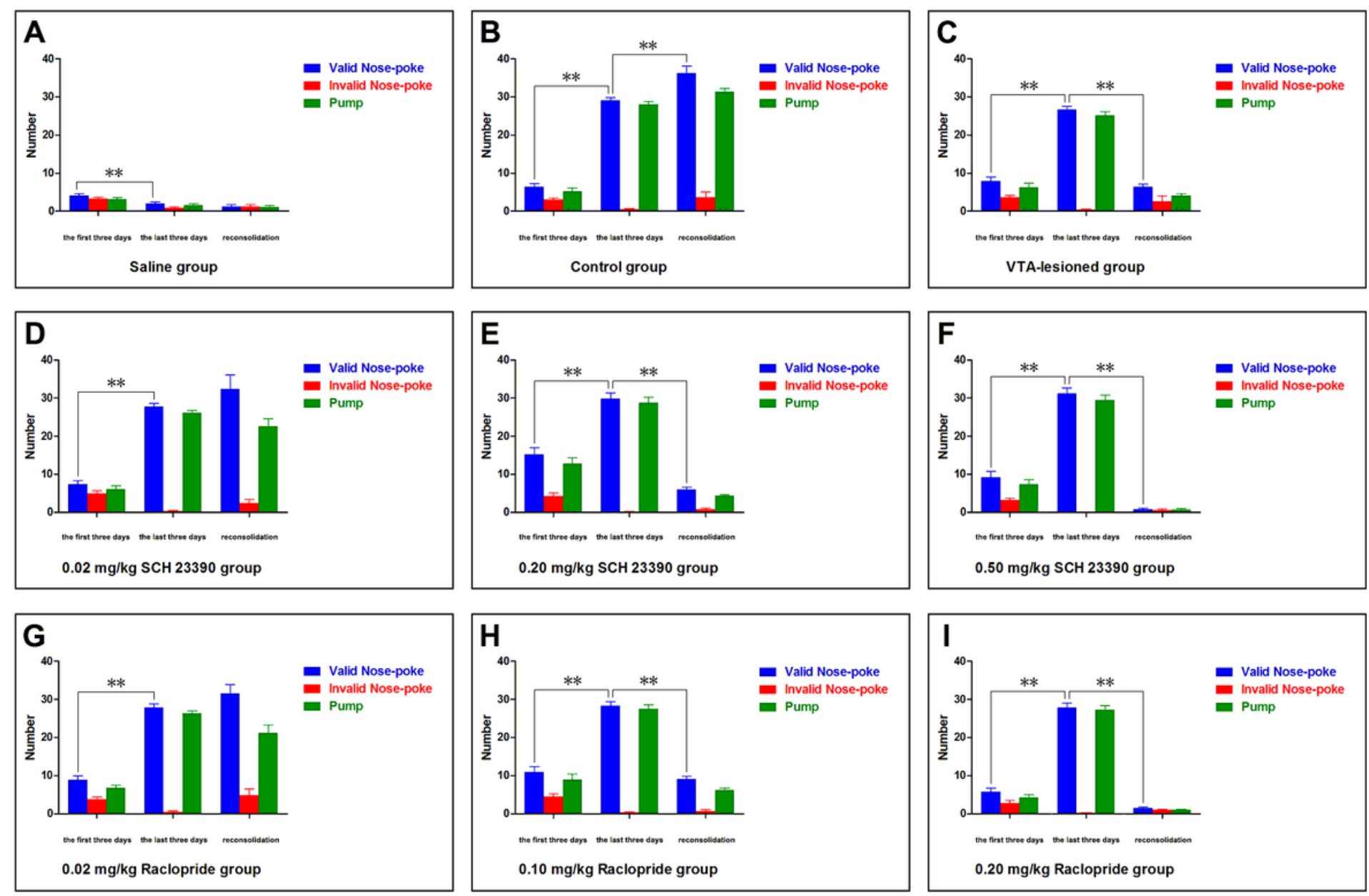

\section{Figure 7}

Compared to the number of valid nose poke for the first three days, that for the last three days showed a significant increasing in every Cocaine-addicted group (tControl group =18.46, $\mathrm{P}<0.01$; tVTA-lesioned group=12.79, $\mathrm{P}<0.01 ;$ t0.02 mg/kg SCH23390 group=16.48, $\mathrm{P}<0.01 ;$ t0.20 mg/kg SCH23390 group=6.228, $\mathrm{P}<0.01 ;$ t0.50 mg/kg SCH23390 group=10.24, $\mathrm{P}<0.01 ; \mathrm{t} 0.02 \mathrm{mg} / \mathrm{kg}$ Raclopride group=13.91, $\mathrm{P}<0.01 ; \mathrm{t} 0.10$ $\mathrm{mg} / \mathrm{kg}$ Raclopride group=9.565, $\mathrm{P}<0.01 ; \mathrm{t} 0.20 \mathrm{mg} / \mathrm{kg}$ Raclopride group=14.55, $\mathrm{P}<0.01)$. In contrast, there was a little decreasing for that in Saline group (tSaline group=2.977, $\mathrm{P}<0.01)$. Next, the number of "valid" nose poke showed a significant decreasing before and after cue-induced cocaine memory reconsolidation in the following groups (t'VTA-lesioned group=12.79, $\mathrm{P}<0.01 ; \mathrm{t}^{\prime} 0.20 \mathrm{mg} / \mathrm{kg} \mathrm{SCH} 23390$ group $=8.978, \mathrm{P}<0.01 ; \mathrm{t}^{\prime} 0.50 \mathrm{mg} / \mathrm{kg} \mathrm{SCH} 23390$ group $=11.66, \mathrm{P}<0.01 ; \mathrm{t}^{\prime} 0.10 \mathrm{mg} / \mathrm{kg}$ Raclopride group=10.39, $\mathrm{P}<0.01 ; \mathrm{t}^{\prime} 0.20 \mathrm{mg} / \mathrm{kg}$ Raclopride group=12.52, $\left.\mathrm{P}<0.01\right)$, While there were no significant change for that in Saline, low SCH 23390 and low raclopride group ( $t$ 'Saline group=1.090, $P=0.2855$; t'0.02 mg/kg SCH23390 group=1.863, $\mathrm{P}=0.0738 ; \mathrm{t}^{\prime} 0.02 \mathrm{mg} / \mathrm{kg}$ Raclopride group=1.758, $\mathrm{P}=0.0904$ ). Interestingly, that in Control group showed a significant increasing ( $t^{\prime}$ Control group $\left.=4.221, P<0.01\right)$. Data were presented as means $\pm \mathrm{SEM},{ }^{\star *} \mathrm{P}<0.01$. 


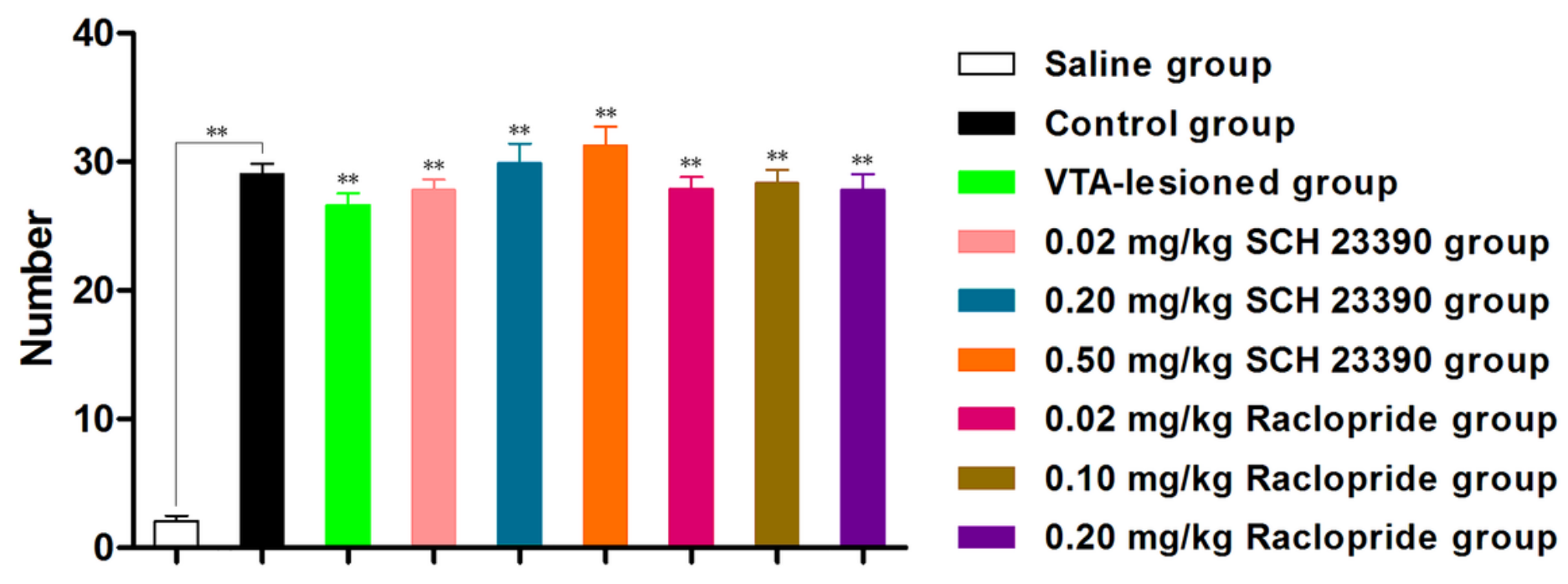

\section{Valid Nose-poke during the last three days}

Figure 8

The number of valid nose poke for the last three days between every Cocaine-addicted group and Saline group all showed a significant increasing (Day12 14 in Saline group: $2.095 \pm 0.4018$; Day12 14 in Control group: $29.06 \pm 0.8023$; Day12 14 in VTA-lesioned group: $26.67 \pm 0.8737$; Day12 14 in 0.02 mg/kg SCH23390 group: $27.81 \pm 0.8036$; Day12 14 in 0.20 mg/kg SCH23390 group: $29.90 \pm 1.502$; Day12 14 in 0.50 mg/kg SCH23390 group: $31.24 \pm 1.481$; Day12 14 in 0.02 mg/kg Raclopride group: $27.90 \pm 0.9256$; Day12 14 in 0.10 mg/kg Raclopride group: $28.33 \pm 1.036$; Day12 14 in $0.20 \mathrm{mg} / \mathrm{kg}$ Raclopride group: $27.86 \pm 1.198$. tControl group, Saline group=31.38, $\mathrm{P}<0.01$; tVTA-lesioned group, Saline group=24.38, $\mathrm{P}<0.01 ;$ t0.02 mg/kg SCH23390 group, Saline group=28.62, $\mathrm{P}<0.01 ;$ t0.20 mg/kg SCH23390 group, Saline group=17.88, $\mathrm{P}<0.01 ; \mathrm{t0} .50 \mathrm{mg} / \mathrm{kg} \mathrm{SCH} 23390$ group, Saline group=18.99, $\mathrm{P}<0.01 ; \mathrm{t} 0.02$ $\mathrm{mg} / \mathrm{kg}$ Raclopride group, Saline group=25.58, $\mathrm{P}<0.01 ; \mathrm{t} 0.10 \mathrm{mg} / \mathrm{kg}$ Raclopride group, Saline group=23.62, $\mathrm{P}<0.01 ; \mathrm{t} 0.20 \mathrm{mg} / \mathrm{kg}$ Raclopride group, Saline group=20.39, $\mathrm{P}<0.01$ ). In addition, there was no significant difference for the number of valid nose poke for the last three days among every Cocaine-addicted group $(F=1.706, P=0.1111)$. Data were presented as means $\pm S E M, * \star P<0.01$. 


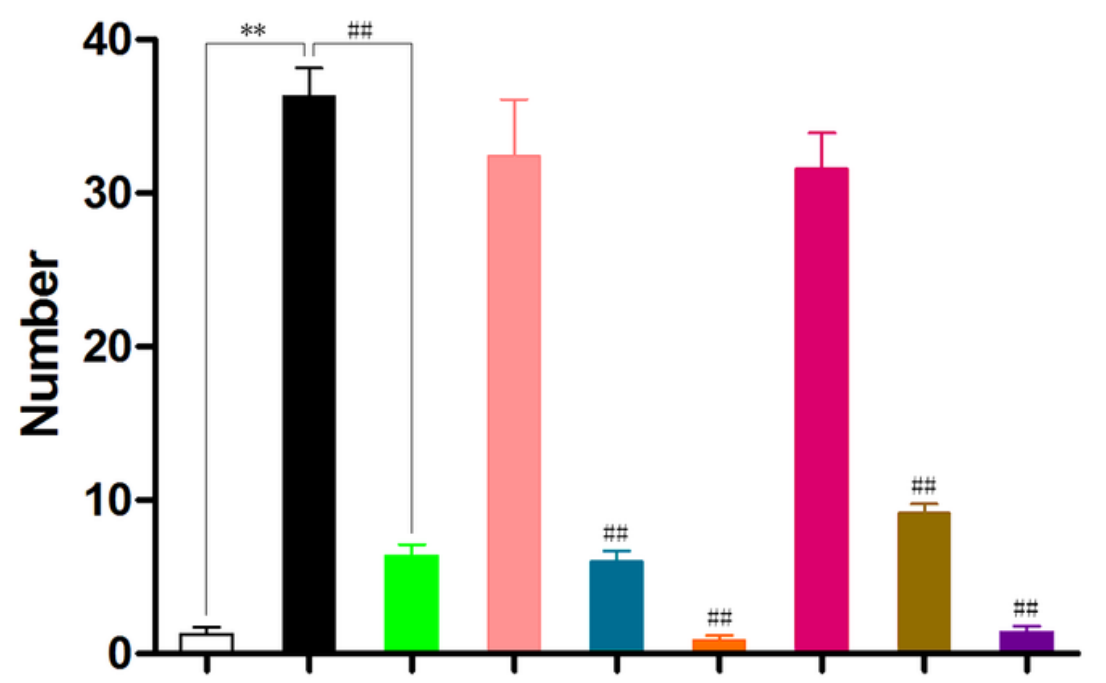

$\square$ Saline group

- Control group

VTA-lesioned group

$0.02 \mathrm{mg} / \mathrm{kg} \mathrm{SCH} 23390$ group

$0.20 \mathrm{mg} / \mathrm{kg} \mathrm{SCH} 23390$ group

$0.50 \mathrm{mg} / \mathrm{kg} \mathrm{SCH} 23390$ group

0.02 mg/kg Raclopride group

$0.10 \mathrm{mg} / \mathrm{kg}$ Raclopride group

$0.20 \mathrm{mg} / \mathrm{kg}$ Raclopride group

\section{Valid Nose-poke during reconsolidation}

Figure 9

The number of "valid" nose poke before and after cue-induced cocaine memory reconsolidation between Control group and Saline group showed a significant increasing (Day29 in Saline group: $1.286 \pm 0.4206$, Day29 in Control group: $36.33 \pm 1.801$, $t^{\prime}$ Control group, Saline group=20.41, $\left.P<0.01\right)$. The number of "valid" nose poke between VTA-lesioned/high SCH 23390/high raclopride group and Control group all showed a significant decreasing during cue-induced cocaine addictive memory reconsolidation (Day29 in Control group: $36.33 \pm 1.801$; Day29 in VTA-lesioned group: $6.375 \pm 0.7545$; Day29 in $0.20 \mathrm{mg} / \mathrm{kg}$ SCH23390 group: $6.000 \pm 0.6901$; Day29 in $0.50 \mathrm{mg} / \mathrm{kg} \mathrm{SCH} 23390$ group: $0.8571 \pm 0.3401$; Day29 in $0.10 \mathrm{mg} / \mathrm{kg}$ Raclopride group: $9.143 \pm 0.5948$; Day29 in $0.20 \mathrm{mg} / \mathrm{kg}$ Raclopride group: $1.429 \pm 0.3689$. t'VTA-lesioned group, Control group=16.91, $\mathrm{P}<0.01 ; \mathrm{t}^{\prime} 0.20 \mathrm{mg} / \mathrm{kg} \mathrm{SCH} 23390$ group, Control group=16.69, $\mathrm{P}<0.01 ; \mathrm{t}^{\prime} 0.50 \mathrm{mg} / \mathrm{kg} \mathrm{SCH} 23390$ group, Control group $=20.92, \mathrm{P}<0.01 ; \mathrm{t}^{\prime} 0.10 \mathrm{mg} / \mathrm{kg}$ Raclopride group, Control group=15.30, $\mathrm{P}<0.01 ; \mathrm{t}^{\prime} 0.20 \mathrm{mg} / \mathrm{kg}$ Raclopride group, Control group=20.50, $\mathrm{P}<0.01$ ). However, there was no significant difference for that between low SCH 23390/low raclopride group and Control group during cue-induced cocaine memory reconsolidation (Day29 in Control group: $36.33 \pm 1.801$; Day29 in 0.02 mg/kg SCH23390 group: $32.43 \pm 3.677$; Day29 in 0.02 mg/kg Raclopride group: $31.57 \pm$ 2.359. t'0.02 mg/kg SCH23390 group, Control group $=0.9026, P=0.3861 ; t^{\prime} 0.02 \mathrm{mg} / \mathrm{kg}$ Raclopride group, Control group $=1.560, P=0.1470$ ). Data were presented as means $\pm S E M, \star * P<0.01$.

\section{Supplementary Files}

This is a list of supplementary files associated with this preprint. Click to download.

- GraphicalAbstract.tif

- Supplementarymaterials.pdf 
- Video.avi

Page 27/27 